\title{
Attitudes of operating theater workers toward patient safety
}

\author{
Fatma SUSAM ÖZSAYIN', Türkan ÖZBAYIR² \\ İzmir Katip Çelebi University, Atatürk Training and Research Hospital, Management of Health Care Services, Izmir-Turkey \\ ${ }^{2}$ Ege University Faculty of Nursing, Department of Surgical Nursing, İzmir-Turkey
}

\begin{abstract}
SUMMARY
Objective: This research was performed to evaluate the attitudes of operating theater staff members toward patient safety.

Methods: A survey was conducted of 200 operating theater members of staff (surgeons, surgical assistants, anesthetists, assistant anesthetists, anesthesia technicians, anesthesia nurses, and operating theater nurses) at Izmir Katip Çelebi University Atatürk Training and Research Hospital. An employee information form and the version of the Safety Attitudes Questionnaire (SAQ) designed for operating theater employees were used to collect data in six areas: team cooperation, job satisfaction, thoughts on management, safety environment, working conditions and stress level. Average, standard deviation, frequency, and percentage were used to provide descriptive data. One-way analysis of variance (ANOVA), $\mathrm{t}$-test, Kruskall-Wallis $\mathrm{H}$ test, and Mann-Whitney $\mathrm{U}$ test were used to evaluate the data. Results: Data indicated that $42.5 \%$ of operating theater employees surveyed were between the ages of $30-39$. It was determined that $33.5 \%$ of the group were surgeons, $14.5 \%$ were anesthetists, and $41 \%$ were operating theater nurses; $37 \%$ had 11 or more years of experience in their field of specialization. According to the research, $46.5 \%$ of the employees had participated in an orientation program when they first started to work at the hospital. The SAQ mean score for job satisfaction it was $63.13 \pm 20.27$, the mean for stress levels was $28.55 \pm 14.67$, and the total mean score for patient safety attitude was $52.51 \pm 11.78$. When mean scores for patient safety were compared according to participants' area of expertise using Kruskall-Wallis analysis, it was found that there was a statistically significant difference. It was also determined that employees who have specialized experience of 6-10 years and 11 years or more, had been participants in job training or had attended an orientation program had higher safety attitude point average.

Conclusion: A plan was proposed to reduce employee stress levels, regulate work hours, have operating theater employees attend an orientation program, improve communication and collaboration between and among teams, and to support operation theater employees and directors joining educational programs related to patient safety.

Keywords: Attitudes toward patient safety; culture of patient safety; patient safety.
\end{abstract}

How to cite: Özsayın FS, Özbayır T. Attitudes of operating theater workers toward patient safety. Int J Antisep Disinfect Steril 2016;1(1):1-6.

Correspondenceः Fatma Susam Özsayın. İzmir Katip Çelebi Üniversitesi, Atatürk Eğitim ve Araştırma Hastanesi

Sağlık Bakım Hizmetleri Müdürlüğü, Süpervizör Hemşirelik Birimi, Yeşilyurt, Karabağlar İzmir.

Tel: +90232 - 2434343 e-mail: ftmsusam@gmail.com

Submittedः March 11, 2016 Acceptedः May 11, 2016 Available online dateः May 10, 2016

Society of Disinfection Antisepsis Sterilization @ C2016 $_{2}$ Production by Kare Publishing on behalf of the Owner.

This is an open access article under the CC BY-NC-ND license (http://creativecommons.org/licenses/by-nc-nd/4.0/). 
$\mathrm{O}$ ne of the most important topics for quality programs in health service is patient safety ${ }^{[1]}$ In the United States, the most influential organization guiding medical practice, the Institute of Medicine (IOM), defines patient safety as "the prevention of harm which could come to a patient." ${ }^{2]}$ It states that this can be achieved with a care system founded on a culture of safety that includes health care workers, institutions, and patients, and in which mistakes are prevented, and lessons are learned from mistakes that are made. ${ }^{[3]}$

An increase in the intricacy as well as the number of health services now provided has led to greater awareness of the importance of the concept of patient safety in all hospital services. Providing patient safety at every stage and preventing medical errors is an institutional priority. The purpose of health services is to provide patients with care and treatment, protection from disease, and rehabilitation. Complex treatment and care procedures, rapid changes in the health field and a reduction in the number of qualified health workers threaten patient safety. ${ }^{[4]}$ Though they may mean additional expense for the hospital, actions taken related to patient safety prevent harmful effects. ${ }^{[5]}$

In a retrospective study of 1014 patients, $10.8 \%$ had experienced adverse effects from services received. Approximately half of the mistakes were avoidable. Different types of failures were observed, from a simple mistake to one resulting in death. ${ }^{[6]}$ It has been stated that in industrialized countries, about half of harmful effects to patients are related to surgery and $5 \%$ of them can be avoided. ${ }^{[7]}$

In the United States, surgical complications arise in $40 \%$ of surgeries performed each year. The most common surgical complications are surgical site infections, cardiovascular complications, postoperative venous thromboembolism and ventilator-associated pneumonia. ${ }^{[8]}$

The reporting of errors related to patient safety in Turkey has been analyzed and it was found that a significant portion of health professionals surveyed $(71.3 \%)$ was unable to report any incident that may have endangered patient safety. ${ }^{[9]}$ In another study carried out in Turkey, it was found that prophylactic antibiotic is administered to $59 \%$ of patients undergoing surgical operation. Medical errors have been the cause of numerous post-operative and peri-operative complications. ${ }^{[10]}$

The present study evaluates attitudes of operating theater workers toward patient safety, factors affecting those attitudes, and differences between them.

\section{Materials and methods}

The study was conducted between December 2014 and January 2015 at İzmir Katip Çelebi University Atatürk Research and Education Hospital. The population group consisted of the 354 people working in the central operating theater of the hospital (surgeons and surgical assistants, anesthetists, assistant anesthetists, anesthesia technicians, anesthesia nurses, and operating theater nurses). Criterion sampling method was used to form a study sample of 200 people who had at least 1 year of experience working in the operating theater. Prior to beginning the research, written permission was obtained from the Scientific Ethics Committee of Ege University Nursing Faculty and the Southern Secretariat of the Public Health Association, and oral permission was obtained from the employees.

An employee information form and the Safety Attitudes Questionnaire (SAQ) version for operating theater were used to collect data. There were 21 questions that included age, gender, marital status, education level, position at work, year of graduation, average working hours, years of experience in their professional specialty, whether they knew of in-service training opportunities at the hospital and if they had participated, and whether they had had training in patient safety.

The operating room version of SAQ was developed by Sexton et al. at the University of Texas to measure attitudes of operating theater employees toward patient safety. Validity and reliability studies were carried out in 2006. ${ }^{[11]}$ Data are collected in six areas relating to team cooperation, job satisfaction, thoughts on method, safety environment, working conditions and stress levels. A 5 -point Likert-type scale is used for responses ( $1=\mathrm{I}$ completely disagree, $2=\mathrm{I}$ disagree, $3=\mathrm{I}$ am undecided, $4=\mathrm{I}$ agree, $5=\mathrm{I}$ completely agree). Items containing negative statements $(1,12,16,24,25,27,31,32,33,36,39,44$, $47,49,52,53,56,58)$ are scored in reverse: a higher score denotes a more positive attitude. Scores are converted to percentages thus: $1=0,2=25,3=50,4=75,5=100 .^{[12-14]}$

SPSS software (version 17.0; SPSS Inc., Chicago, IL, USA) was used to analyze the data. Frequencies, percentages, means and standard deviations were used to present the data. One-way variance analysis (ANOVA), t-test, Kruskall-Wallis $\mathrm{H}$ test and Mann-Whitney $\mathrm{U}$ test were used to determine correlations between the data.

\section{Results}

The study sample consisted of 200 individuals working in the central operating theater of Izmir Katip Çelebi 
Table 1. Distribution of workers by age, gender and marital status.

\begin{tabular}{lcc}
\hline Variables & No. & $\%$ \\
\hline $\begin{array}{l}\text { Gender } \\
\text { Female }\end{array}$ & & \\
Male & 112 & 56.0 \\
Age & 88 & 44.0 \\
$18-29$ & & \\
$30-39$ & 32 & 16.0 \\
$40-49$ & 85 & 42.5 \\
$\geq 50$ & 60 & 30.0 \\
Marital status & 23 & 11.5 \\
Married & & \\
Single & 151 & 75.5 \\
\hline
\end{tabular}

University Atatürk Teaching and Research Hospital.

It was determined that $16 \%$ of participants were between the ages of 18 and 29, 42.5\% were between 30 and 39 years of age, $30 \%$ were between 40 and 49 , and $11.5 \%$ were aged 50 or over. Of the total, $56 \%$ were female, and $75.5 \%$ were married (Table 1 ).

It was found that $33.5 \%$ of the work group were surgeons, $14.5 \%$ were anesthetists, $5.5 \%$ were anesthesia nurses, $5.55 \%$ were anesthesia technicians, and $41 \%$ were operating theater nurses (Table 2).

The data indicated that $36.5 \%$ of the work group had 1-5 years of experience in their field of specialization, $26.5 \%$ had $6-10$ years of experience, and $37 \%$ had 11 or more years of experience (Table 3).

When joining the staff at İzmir Katip Çelebi University Atatürk Research and Education Hospital, $46.5 \%$ of the study group participated in an orientation program (Table 4).

The mean SAQ scores were as follows: team cooperation was $62.60 \pm 13.82$, job satisfaction was $63.13 \pm 20.27$, thoughts on method was $52.79 \pm 19.09$, safe environment was $56.89 \pm 15.10$, working conditions was $58.04 \pm 26.00$, and stress level was $28.55 \pm 14.67$;
Table 2. Distribution of participants by specialty.

\begin{tabular}{lcc}
\hline Characteristic & No. & \% \\
\hline Position & & \\
$\quad$ Surgeon & 67 & 33.5 \\
Anesthetist & 29 & 14.5 \\
Anesthesia Nurse & 11 & 5.5 \\
Anesthesia Technician & 11 & 5.5 \\
Operating Theater Nurse & 82 & 41 \\
\hline
\end{tabular}

Table 3. Distribution of participants by years of experience in specialty.

\begin{tabular}{lll}
\hline Characteristic & No. & $\%$ \\
\hline Years of experience in specialty & & \\
1-5 years & 73 & 36.5 \\
6-10 years & 53 & 26.5 \\
11 years or more & 74 & 37.0 \\
\hline
\end{tabular}

Table 4. Distribution by participation in orientation program upon employment at hospital.

\begin{tabular}{lcc}
\hline Characteristic & No. & $\%$ \\
\hline Participation in orientation program & & \\
Yes & 93 & 46.5 \\
No & 107 & 53.5 \\
\hline
\end{tabular}

the total mean score for patient safety attitude was 52.51 \pm 11.78 (Table 5).

Kruskall-Wallis analysis of mean patient safety attitude results compared according to specialty revealed a statistically significant difference between the groups $(p<0.05)$. It was established by Mann-Whitney U test post-hoc analysis that there was a significant difference between surgeons and anesthesia nurses, anesthesia technicians and operation theater nurses, and between anesthetists and anesthesia nurses, anesthesia technicians and operating theater nurses (Table 6).

Table 5. Mean score for patient safety and subdimensions.

\begin{tabular}{lccc}
\hline & Minimum & Maximum & Mean \pm SD \\
\hline Team cooperation & 19.64 & 89.29 & $62.60 \pm 13.82$ \\
Job satisfaction & .00 & 100.00 & $63.13 \pm 20.27$ \\
Thoughts on method & .00 & 100.00 & $52.79 \pm 19.09$ \\
Safety environment & 7.35 & 85.29 & $56.89 \pm 15.10$ \\
Working conditions & -8.33 & 100.00 & $58.04 \pm 26.00$ \\
Stress level & -2.08 & 91.67 & $28.55 \pm 14.67$ \\
Total patient safety attitude & 10.78 & 76.72 & $52.51 \pm 11.78$ \\
\hline
\end{tabular}


Table 6. Comparison of Safety Attitudes Questionnaire mean score and participant specialization.

\begin{tabular}{lccccc}
\hline & No & $\begin{array}{c}\text { Mean } \\
\text { order }\end{array}$ & H & p & $\begin{array}{c}\text { Significant } \\
\text { difference }\end{array}$ \\
\hline Surgeon (1) & 67 & 79.79 & & & $1-3$ \\
Anesthetist (2) & 29 & 63.88 & & & $1-4$ \\
Anesthesia Nurse (3) & 12 & 139.80 & 39.926 & 0.000 & $1-5$ \\
Anesthesia Technician (4) & 11 & 135.41 & & & $2-3$ \\
Operating Theater Nurse (5) & 81 & 119.85 & & & $2-4$ \\
& & & & & $2-5$ \\
\hline
\end{tabular}

Table 7. Comparison of mean Safety Attitudes Questionnaire score according to specialty experience.

\begin{tabular}{lccccc}
\hline & No & Mean \pm SD & F & p & $\begin{array}{c}\text { Significant } \\
\text { difference }\end{array}$ \\
\hline $1-5$ years & 73 & $49.19 \pm 12.44$ & & & $1-2$ \\
6-10 years & 53 & $54.39 \pm 9.48$ & 4.721 & 0.010 & $1-3$ \\
$\geq 11$ years & 74 & $54.43 \pm 12.02$ & & & \\
\hline
\end{tabular}

Table 8. Comparison of mean Safety Attitudes Questionnaire score according to specialty experience.

\begin{tabular}{lccccc}
\hline & No & Mean \pm SD & t & p \\
\hline Yes & 93 & $55.75 \pm 10.69$ & 3.743 & 0.000 \\
No & 107 & $49.69 \pm 12.01$ & & \\
\hline
\end{tabular}

When the number of years of specialized experience was compared with mean patient safety attitude scores by one-way variance analysis (ANOVA), a statistically significant difference was found between experience and average attitude scores $(\mathrm{p}<0.05)$. It was established by post-hoc analysis that there was a significant difference between those with 1-5 years of experience and those with 6-10 years of experience, as well as those with 11 or more years of experience (Table 7).

When a comparison was made by $t$-test of the mean patient safety attitude scores and participation in an orientation program when the participants started to work at the hospital, a significant difference was found $(\mathrm{p}<0.05$, Table 8$)$.

\section{Discussion}

In a study by Sexton et al, it was found that the mean score on the sub-dimension of stress levels on the SAQ was 54.7 $\pm 26.6 .{ }^{[11]}$ According to a study conducted in Turkey, it was found that the mean score on the SAQ sub-dimension of stress levels was $67 \pm 17.59 .^{[15]}$ In a survey of operating room staff - both surgeons and op- erating room nurses - at 17 hospitals in Scotland participants stated that stress had not affected their performances. ${ }^{[16]}$ However, Flinn et al. stated in a study of 222 anesthesiologists that $83 \%$ of participants reported that stress and fatigue had an adverse affect on their performance. ${ }^{[17]}$

When mean SAQ scores of operating theater employees were examined in this study, it was established that total mean score for patient safety attitude was $52.51 \pm 11.78$. Mean scores on the subscale of job satisfaction were the highest, $63.13 \pm 20.27$, and those on the subscale of stress level were lowest, $28.55 \pm 14.67$. In a study by Sexton et al, it was found that SAQ mean scores on the subdimension of stress level were $54.7 \pm 26.6 .{ }^{[3]}$ Pressure and the delicate nature of operating theater work in addition to high turnover of patients as well as employees increase workers' stress levels.

Research conducted by Önler and Akyolcu revealed no statistically significant difference in mean safety attitude scores of doctors, nurses and anesthetists in the sampling group of the study. ${ }^{[15]}$ In a study conducted by Prati and Pietrantoni on the safety attitudes of operating theater nurses and surgeons in Italy, a statistically signifi- 
cant difference was found between professional groups. ${ }^{[18]}$ The present study also a found statistically significant difference $(p<0.05)$; the mean SAQ scores of anesthesia nurses, anesthesia technicians and operating theater nurses were significantly higher than those of surgeons and anesthetists. It is thought that this difference may be an effect of the fact that at the institution where the study took place, anesthesia technicians, anesthesia nurses and operating theater nurses take part more regularly in in-service training programs on patient safety than do surgeons and anesthetists.

Önler and Akyolcu, determined that the mean safety attitude scores of those who had been working in their field of specialization for 6-11 years were lower than those of individuals with more than 11 years of experience. ${ }^{[15]}$ In the present study, a statistically significant difference was found between experience in the field of specialty and mean attitude scores $(p<0.05)$. It is an expected result that as professional experience increases, patient safety attitudes would increase.

In a study by Beuzekum et al., it was stated that lack of education and experience was the source of most medical errors. ${ }^{[19]}$ Önler and Akyolcu reported that whether or not operating theater workers had taken part in an orientation program when they started to work at the hospital did not yield a significant difference in mean patient safety attitude scores. ${ }^{[15]}$ In the present study, a significant difference was found between mean patient safety attitude scores based on whether the participant had taken part in an orientation program when they started to work at the hospital $(\mathrm{p}<0.05)$. The patient safety attitude scores of those who had participated in an orientation program were found to be significantly higher than those of individuals who had not. These results are in accordance with the literature.

According to the results of the study, a measure that must be taken in order to improve the patient safety climate is to remove work stress, or at least reduce the level to a minimum. Factors increasing the stress level in the operating room should be determined, and steps should be taken to eliminate them. Employees should be trained to cope with stress and all employees should participate.

It is recommended that the whole team regularly attend training programs in order to form a culture of patient safety. Operating theater employees should be encouraged to join an orientation program before beginning to work in the hospital. It is also suggested that sufficient well-educated employees and equipment be provided, that working hours be adjusted, directors be provided with support, and operating room team cooperation and communication be improved.
Acknowledgements: The study was presented as a free paper at the 7th European Operating Room Nurses Association Congress in Rome, May 4-10, 2015.

Conflict of interest: None declared.

Peer-review: Externally peer-reviewed.

Authorship contributions Concept - Design - Supervision - Resource - Materials - Data collection - Literature search - Writing: F.S.Ö, T.Ö.

\section{References}

1. Hakverdioğlu YG. Patient safety culture. Journal of Ege University School of Nursing 2011;27:77-82.

2. Institue of Medicine (I.O.M.). To Err is Human: Building a Safer Health System 2000. Accessed: 22.05.2014 http:// www.nap.edu/catalog/9728.html.

3. Mitchell PM. Defining patient safety and quality care 2008. Accessed: 15.03.2014 http://www.ncbi.nlm.nih.gov/books/ NBK2681/.

4. Yıldız T, Eriten G, Erdem İ, Gökay NS, Kulaç M, Alp R. Graduation and work as health professionals effects on patient safety awareness. Kafkas J Med Sci 2012;2:94-8. Crossref

5. Karaca A, Arslan H. A study for the assessment of patient safety culture in nursing services. Journal of Health and Nursing Management 2014;1:9-18.

6. Vincent CA, Coulter A. Patient safety: what about the patient? Qual Saf Health Care 2002;11:76-80. Crossref

7. Etchells E, O'Neill C, Bernstein M. Patient safety in surgery: error detection and prevention. World J Surg 2003;27:93642. Crossref

8. Demir F. Patient safety in surgery. In: Turkish Surgical and Operating Room Nursing Congress (with international participation) Gaziantep, 2007;28-33.

9. Dursun S, Bayram N, Aytaç S. An application on patient safety culture. Celal Bayar University Journal of Social Sciences 2010;8:1-14.

10. Hergül KF, Özbayır T, Gök F. Patient safety in the operating room: systematic review. Pamukkale Medical Journal 2016;9:87-8. Crossref

11. Sexton JB, Helmreich RL, Neilands TB, Rowan K, Vella K, Boyden J, et al. The Safety Attitudes Questionnaire: psychometric properties, benchmarking data, and emerging research. BMC Health Serv Res 2006;6:44. Crossref

12. Makary MA, Sexton JB, Freischlag JA, Millman A, Pryor D, Holzmueller CG, et al. Patient safety in surgery. Ann Surg 2006;243:5. Crossref

13. Patterson PD, Huang DT, Fairbanks RJ, Wang HE. The emergency medical services safety attitudes questionnaire. Am J Med Qual 2010;25:109-15. Crossref

14. Shteynberg G, Sexton B, Thomas E. Test retest reliability of the safety climate scale. Technical report 2005. Accessed 
22.05.2014, www.uth.tmc.edu/...safety/.../ Safety-ClimateTest-Retest-Tech-Report.doc.

15. Önler E, Akyolcu N. Evaluation of operating room staff's attitudes related to patient safety. İstanbul University, Institute of Health Science, Department of Surgical Nursing. Doctorate Dissertation, İstanbul 2010.

16. Flin R, Yule S, McKenzie L, Paterson-Brown S, Maran N. Attitudes to team work and safety in the operating theatre. Surgeon 2006;4:145-51. Crossref
17. Flin R, Fletcher G, McGeorge P, Sutherland A, Patey R. Anaesthetists' attitudes to team work and safety. Anaesthesia 2003;58:233-42. Crossref

18. Prati G, Pietrantoni L. Attitudes to teamwork and safety among Italian surgeons and operating room nurses. Work 2014;49:669-77.

19. Van Beuzekom M, Boer F, Akerboom S, Dahan A. Perception of patient safety differs by clinical area and discipline. $\mathrm{Br}$ J Anaesth 2013;110:107-14. Crossref

\section{Ameliyathane çalıșanlarının hasta güvenliği tutumları}

\section{Fatma SUSAM ÖZSAYIN, Türkan ÖZBAYIR}

Amaç: Bu çalışma, ameliyathane çalışanlarının hasta güvenliği tutumlarını değerlendirmek amacıyla yapıldı.

Yöntemler: İzmir Katip Çelebi Üniversitesi Atatürk Eğitim ve Araştırma Hastanesi çalışanı 200 kişi (cerrah, anestezist, anestezi hemşiresi, anestezi teknisyeni ve ameliyathane hemşiresi) araştırma kapsamına alındı. Veriler Güvenlik Tutumları Ölçeği ve Çalışan Bilgi Formu kullanılarak elde edildi. Güvenlik Tutumları Ölçeği-GTÖ (Safety Attitudes Questionnaire-SAQ-Operating RoomVersion) Teksas Üniversitesinde Sexton ve arkadaşları tarafından ameliyathane çalışanlarının hasta güvenliğine ilişkin tutumlarını ölçmek amacıyla geliştirilmiş ve geçerlik güvenirlik çalışması 2006 yılında yapılmış bir ölçektir. Ekip işbirliği, iş memnuniyeti, yönetimle ilgili düşünceler, güvenli ortam, çalışma koşulları ve stres düzeyinin belirlenmesi gibi güvenliğin sağlanmasıyla ilgili 6 alanda veri toplamamızı sağlayan ölçeğin, bazı maddeleri olumsuz ifadeler içermektedir. Olumsuz ifadeler ters çevrilerek puanlandığ için; daha yüksek puan, daha olumlu tutumlar anlamına gelmektedir. Verileri betimsel olarak sunmak için frekans, yüzde, ortalama ve standart sapma kullanıldı. Veriler arasındaki ilişkiyi belirlemek amacıyla tek yönlü varyans analizi (ANOVA), t testi, Kruskall Wallis H Testi, Mann Whitney U Testi kullanıld. Araştırma öncesi Ege Üniversitesi Hemşirelik Fakültesi Bilimsel Etik Kurulundan, araştırmanın yapılabilmesi için Kamu Hastaneler Birliği Güney Sekreterliğinden yazılı izin ve ameliyathane çalışanlarından sözlü izin alındı.

Bulgular: Ameliyathane çalışanların \%42,5'i 30-39 yaşları arasında idi. Çalışma grubunun \%33.5'i cerrah, \%14.5'i anestezist, \%41'i ameliyathane hemşiresiydi ve \%37'si bulundukları uzmanlık alanında 11 yıl ve üstü deneyimleri olduklarını belirttiler. Çalışanların $\% 46.5$ ' $\mathrm{i}$ işe yeni başladıklarında oryantasyon programı uygulandığını belirtmiştir. Çalışma grubundaki personelin Güvenlik Tutumları Ölçeği ortalama puanları incelendiğinde, iş memnuniyeti için ortalama puanı $63.13 \pm 20.27$, stres düzeyinin belirlenmesi için ortalama puanı $28.55 \pm 14.67$ ve hasta güvenliği tutumlarının toplam puanlarının ortalamaları $52.51 \pm 11.78$ olarak saptandı. Ameliyathane çalıșanlarının pozisyonları ile hasta güvenliği tutum puanları ortalaması Kruskal Wallis analizi ile karșılaștırıldığında; pozisyon gruplarının puan ortalamaları arasında istatistiksel olarak anlamlı fark olduğu saptanmıştır. Ameliyathanede çalışanların tanıtıcı özellikleri ile, güvenlik tutumları karşılaştırıldığında; 6-10 yıl ve 11 yıl ve daha fazla süreyle uzmanlık deneyimi olanlar, kurumda çalışmaya başlarken oryantasyon programına katılanlar ile kurumda hizmet içi eğitim programlarına katılanların güvenlik tutumları puan ortalamalarının yüksek, aralarındaki farkın anlamlı olduğu belirlendi.

Sonuç: Çalışanların stres düzeyini azaltacak uygulamaların planlanması, çalışma saatlerinin yasalara göre düzenlenmesi, kurumda çalışmaya başlamadan önce tüm çalışanların oryantasyon programına katılması, meslek gruplarının birbirleri ve diğer ekip üyeleri ile iletişim ve işbirliğini geliştirecek uygulamaların düzenlenmesi, hasta güvenliği ile ilgili hizmet içi eğitim programları hazırlanıp yönetim kadrosu da dahil edilerek tüm çalışanların katılması önerilir. Anahtar sözcükler: Hasta güvenliği; hasta güvenliği kültürü; hasta güvenliği tutumları.

Int J Antisep Disinfect Steril 2016;1(1):1-6 doi: 10.14744/ijads.2016.98608 